\title{
DUDÁS Katalin
}

\section{VERSENYELÖNY-E A VÁLLALATI KÖRNYEZETTUDATOSSÁG?}

A cikk célja annak a kérdésnek a megválaszolása, hogy versenyelônnynek tekinthetô-e a vállalati környezettudatosság. A szerző által áttekintett szakirodalmi elemzések, kutatási eredmények szerint az a vállalat tud elổnyre szert tenni, amely környezettudatos lépéseit megfelelő módon teszi meg: a fenntartható fejlődés jegyében igyekszik kifejleszteni egyedi és másolhatatlan pozíciót létrehozó megkülönböztető kompetenciáit; amelyek áthatják a vállalat összes funkcióját, és kompatibilisek stratégiájával; ügyel az ezekhez szükséges erôforrások, képességek és képzettségek meglétére; olyan értékekre helyezi a hangsúlyt, amelyeket egy megfelelő nagyságú, elérhetô fogyasztói szegmens ténylegesen értékel, és a költségeket meghaladó ár megfizetésével honorál.

Ahhoz, hogy a vállalatok ebben a gyorsan változó világban sikeresen tudjanak működni a kompetitív piacokon, szükségük van valamiféle ,elổnyre a versenyben", valamire, amiben jobbak, mint a konkurens vállalatok. Versenyezni sokféle módon lehet, meg kell találni azt a versenydimenziót, amelyben a versenytársak kevésbé jók. A hosszú távú siker érdekében kulcsfontosságú megérteni, mi a versenyelôny lényege, és a sokféle vállalati erõfeszítések közül melyek vezetnek annak eléréséhez.

Tradicionálisan - a komparatív elônnyök tana szerint - az a vállalat volt versenyképes, amely hozzá tudott jutni olcsó erôforrásokhoz. A mai globalizálódott világban azonban, mivel minden vállalat olcsó energiához, nyersanyaghoz (például alternatív, szintetikus anyagok használatával), illetve olcsó munkaerőhöz (tevékenység kitelepítése fejlôdổ országokba) juthat, versenyelôny csak a meglévö erőforrások hatékonyabb kihasználásával érhetô el (Porter - Linde, 1995).

Az erôforrás-alapú közelítés szerint - amely a vállalatot egy sor olyan (megfogható és megfoghatatlan) erôforrás és képesség együtteseként írja le, amelyek meghatározzák, hogy mennyire sikeresen múködik a vállalat a piacon - a versenyelôny annak tulajdonítható, hogy a vállalat olyan értékes erôforrásokkal rendelkezik, amelyek lehetôvé teszik számára, hogy tevékenységét versenytársainál jobban és/vagy olcsóbban végezze. Az erőforrások értékességét azok másolhatat- lansága, tartóssága, kisajátíthatósága és nehéz helyettesíthetôsége adja (Collis - Montgomery 1995).

Porter (1996) a versenyelôny legfontosabb forrását abban látja, hogy a vállalat különbözỗ tevékenységei és funkciói kompatibilisek egymással és erôsítik egymás hatását. Így a működési hatékonyság - amely szerinte azt jelenti, hogy a vállalat ugyanazon tevékenységet jobban végez, mint a versenytársak - önmagában nem jelent versenyelônyt, mert csak egy-egy tevékenységre, funkcióra koncentrál, abból próbálva meg kihozni a maximumot. A különbözô funkciók stratégiai összhangja a versenyelôny megtartásában is fontos szerepet játszik, hiszen az egyes tevékenységek, technikák vagy termékek könnyen utánozhatók, de egy összefüggő rendszer lemásolása már komoly nehézségekbe ütközik. Például azért, mert a különbözô tevékenységek, funkciók kombinálásának módja idôvel egyre javul, és érvényesül az „út-függôség” (path-dependency), amely azt jelenti, hogy a piacra újonnan belépõ vállalat nem képes azonnal ugyanúgy végezni a tevékenységét, mint a már bennlévốk, mert bizonyos idô és fejlôdés kell ahhoz, hogy a rendszer „beérjen".

A képességalapú közelítés is kiemeli azt, hogy a versenytársak által könnyedén másolható dolgokkal (például professzionális felszerelés, menedzsmenttechnika) nem érhetổ el tartós versenyelôny. A fenntartható versenyelốny kulcsa az, hogy ki kell építeni 
olyan egyedi és utánozhatatlan képességeket, amelyekben a vállalat jobb, mint a konkurencia, és hosszú távon is jobb tud maradni (Hayes - Pisano, 1994). Mindamellett a képességek olyan integrált rendszerét kell létrehozni, amelyet a fogyasztók értékelnek, össze kell kötni a vállalat képességeit a fogyasztói igényekkel (Stalk - Webber, 1993).

McGrath és társai (1996) az innovációk jelentôségére hívják fel a figyelmet. Schumpeterre (1950) visszautalva állítják, hogy a vállalat csak innovációk útján tud valami igazán értékeset létrehozni, a meglévô termékekbe, piacokba, technológiákba való beruházások soha nem képviselhetnek akkora értéket. Az innováció segítségével a pozitív jövőértékû vállalatspecifikus erôforrásokhoz és/vagy az eddiginél jobb erôforrás-kombinációkhoz juthat. A vállalatspecifikus erôforrások olyan sajátos kombinációját, amely lehetổvé teszi a vállalati célok elérését, kompetenciáknak nevezzük. Az új kompetencia potenciális versenyelőnyt jelent, lehetôséget ad a vállalatnak, hogy valami újat csináljon. Akkor válik azzá, ha a kompetencia megkülönböztetô, nehezen másolható, és a vállalat sikeresen beágyazza termékeibe és/vagy szolgáltatásaiba, majd pedig el tudja adni a fogyasztóknak. Von Hippel (1988) szerint ennek két útja lehetséges: a vállalat versenytársainál nagyobb hatékonysággal mũködik, és ennek köszönhetôen árelổnyt tud elérni (hatékonysági elổny), vagy pedig olyan terméket kínál a fogyasztóknak, amely olyan megkülönböztetổ értéket nyújt, hogy ezáltal a költségeket jelentôssen meghaladó áron tudja értékesíteni (értékelôny). Fisher (1997) arra hívja fel a figyelmet, hogy pusztán a termékinnovációk nem nyújtanak tartós versenyelônnyt, hiszen a versenytársak könnyen le tudják másolni őket. A profitnövekedés csak idôleges, az elônny pedig átmeneti, újabb innovációkra van szükség. Kampas (2003) is kiemeli, hogy a mai erôs versenyben a vállalatoknak folyamatos termék- és folyamatinnovációkra van szükségük ahhoz, hogy sikeresek legyenek a piacon.

Balachander és Srinivasan (1994) a magas minőséget és az ezzel párosuló árat a versenyelôny kifejezõdésének tekintik. Modelljükben bizonyították, hogy a piacon lévô vállalatok el tudják riasztani a potenciális belépôket azzal, hogy azok a magas ár mögött költséghatékony termelést sejtenek, ami megnöveli a belépési költségeket és lecsökkenti a profitlehetôségeket.

\section{A vállalati környezettudatosság}

Kleiner (1991) szerint egy vállalat csak akkor számít környezettudatosnak, ha a kötelezõ elôírások, törvények teljesítésén túllépve olyan magatartást tanúsít, amelyet a piac még nem vár el. Egy vállalat „zöld” volta nem azzal kezdổik, hogy gyárt egy környezetbarát terméket, hanem azzal, hogy hajlandó folyamatosan kísérletezni azzal, hogy a termelés és az általa előállított termékek (vagyis az egész vállalati müködés) minél kevésbé terheljék a környezetet életciklusuk folyamán.

Menon és Menon (1997) szerint a vállalati környezettudatosság nem más, mint környezeti orientáció és elkötelezettség. Ugyanakkor Banerjee és társai (2003) rámutatnak arra, hogy a környezeti orientáció stratégiai implementáció nélkül hatástalan, éppen ezért az õ definíciójuk a stratégia fontosságára épül: szerintük a vállalati környezettudatosság a vállalat szempontjából releváns környezeti kérdések fontosságának felismerését és a vállalat stratégiai tervébe való integrálását jelenti.

A KÖVET-INEM Hungária (Környezettudatos Vállalatirányítási Egyesület) meghatározása szerint „a környezettudatos irányítás szervezetek (általában vállalatok) mûködtetése olyan módon, hogy a tevékenység, a kibocsátott termékek és szolgáltatások minél kevésbé terheljék a munkahelyi, települési, természeti környezetet, valamint az egészséget". Ennek eszközei a teljesség igénye nélkül: környezetközpontú irányítási rendszer (pl. ISO 14001), tisztább termelés, hulladékminimalizálás, a dolgozók és a vezetők ösztönzése és képzése, öko-marketing, környezeti kommunikáció (pl. környezeti jelentés), környezetbarát termékfejlesztés, környezeti teljesítményértékelés, ökokontrolling.

Véleményem szerint az Unilever küldetésének megfogalmazása is szolgálhat a környezettudatos vállalat definíciójául: $\mathrm{Az}$ Unilever elkötelezte magát, hogy a fogyasztói, vásárlói szükségletek kielégítése mellett, a környezeti szempontokat és a fenntarthatóság eszméjét szem elốtt tartva, folyamatosan, a szervezet egészére kiterjedõen javítja, fejleszti a környezetet (Glaskin, 1996).

A környezettudatosnak tekinthetỗ vállalatok tevékenységi körüket tekintve rendkívül sokfélék lehetnek. Nem csak környezetbarát termékeket gyártó vagy környezetbarát szolgáltatásokat nyújtó cégek tartoznak ide. Látogatást téve a KÖVET-INEM Hungária honlapján láthatjuk ezt a sokféleséget. A KÖVET tagjai nem „zöld mintavállalatok”, de felelôsséget érző cégek, amelyek mũködésüket is e szempontok szerint alakítják, alkalmazzák és terjesztik a környezettudatos vállalatirányítás eszközeit és módszereit.

Hunt és Auster (1990) a vállalati környezettudatosság öt szintjét különítik el egymástól: kezdők, tũzoltók, gondos polgárok, pragmatikusak és proaktivisták. Kívánatosnak tartják, hogy a vállalatok eljussanak 
a proaktivisták közé, vagyis folytassanak aktív környezeti menedzsmentet, prioritásként kezelve a környezeti kérdéseket.

\section{A vállalati köınyezettudatosság megjelenése és fejlödése}

Az 1970-es évekig a természeti környezetnek nem volt számottevõ hatása a vállalat mû́ködésére, azt tradicionálisan extern hatásként tekintették. A gyártás társadalomra és környezetre gyakorolt hatásaival csak a kis számú és kis befolyással rendelkezô környezetvédô szervezetek foglalkoztak. A vállalatoknál a környezeti szempontok figyelembevétele az 1970-es években kezdôdött el, de egészen az 1990-es évek elejéig környezetvédelmi tevékenységük csak a védekezésre és a szennyezés kezelésére (ún. csôvégi technikák alkalmazása) terjedt ki, és a vállalatok nagy többségénél csak akkora mértékû volt, amekkorát a zavaró, korlátozó, versenyképességet rontó tényezőknek tekintett - környezetvédelmi törvények, szabályok megkívántak. A hagyományosan környezetszennyezô iparágak vállalatai előszeretettel telepítették ki tevékenységüket fejlődô országokba, az ottani kevésbé szigorú (vagy esetleg nem létezõ) környezeti szabályozás miatt. Az 1990-es években azonban a természeti környezet romlása az emberiség egyik legnagyobb problémájává, és a közvélemény egyik leggyakrabban emlegetett témájává vált. Riasztó kutatási eredmények láttak - és látnak az óta is - napvilágot, amelyek a levegõ-, talaj- és vízszennyezéssel, ózonlyukkal, üvegházhatással, kihalt és veszélyeztetett állatfajokkal stb. foglalkoznak. Egyre szigorúbb állami törvények és nemzetközi egyezmények, megállapodások születnek a természeti környezet védelme érdekében. A vállalatok mûködésében is egyre növekvố szerepet kapnak a környezetvédelemmel kapcsolatos kérdések, egyrészt a szabályoknak való megfelelés kötelezettsége miatt, másrészt pedig mind több vállalat igyekszik a törvényi előírásoknál szigorúbb környezeti standardoknak megfelelni, hogy így versenyelổnyre tegyen szert (Dowell - Hart - Yeung, 2000; Funk, 2003; Menon - Menon, 1997).

Senge és Carstedt (2001) új ipari forradalomként definiálja azt a folyamatot (párhuzamot vonva Schumpeter „kreatív rombolás” elméletével), amelynek során egyre több vállalat ismeri fel a környezettudatosságban rejlô pozitív lehetôségeket. Ezáltal megnổ a vállalati szektor környezeti érzékenységének szintje, és ez radikálisan új technológiák, termékek, folyamatok és üzleti modellek megjelenését eredményezi a fenntartható fejlődés jegyében. Ezt a környezettudatosságot már nem a törvényi szabályozás, hanem az innová- ciók vezérlik, és ez egy új üzleti logika megjelenését igényli. Az új üzleti logika elemei: egyszerũ termékértékesítés helyett komplex megoldások nyújtása a vevőknek; a fogyasztók bevonása az értékteremtō folyamatba; szolgálatkész alkalmazottak helyett részt vevô tagok; szeparált vállalatok helyett ökológiai közösségek; zárt ajtók helyett nyilvánosság (Senge Carstedt, 2001). Az eredmény pedig egy fenntartható szervezet lehet, amely minden érintettjének hosszú távon is fenntartható hasznot nyújt: a befektetôknek fenntartható hozamot; a társadalomnak és a törvényhozásnak környezeti és társadalmi felelôsségtudatot; a fogyasztóknak használható, megbízható, költséghatékony termékeket és szolgáltatásokat; munkavállalóinak pedig profitábilis, innovatív munkahelyet (Funk, 2003).

Hart és Milstein (1999) is a schumpeteri kreatív romboláshoz hasonlítja, és szintén forradalomnak tekinti ezt a folyamatot. A szerzôk hangsúlyozzák, hogy a folyamatos fejlesztés mást, kevesebbet jelent, mint a kreatív rombolás. A folyamatos termék- és folyamatfejlesztés pusztán az ipar racionalizációját jelenti, fókuszában a jelenlegi teljesítmény áll. Ezzel szemben a kreativ rombolás olyan fenntartható stratégiát eredményez, amely - fundamentális innovációknak köszönhetổen - az ipar megújításához vezet, középpontjában pedig a jövổbeli teljesítmény áll.

\section{Környezettudatos vállalati döntések}

és a vállalat működésére gyakorolt hatásaik

Több szerző is egyetért abban, hogy a környezetvédelem nem pusztán terhes kötelesség a vállalatok számára, hanem - ha jól csinálják - üzletileg is kifizetôdô vállalkozás lehet (Dowell - Hart - Yeung, 2000; Hall - Vredenburg, 2003; Hart, 1997; Holliday, 2001; King - Lenox, 2002; Kleiner, 1991; Lovins - Lovins Hawken, 1999). Reinhardt (1999) szerint nem az a kérdés, hogy megéri-e zöldnek lenni, hanem az, hogy adott környezetvédelmi befektetés milyen körülmények között hoz hasznot. Arra is rámutat, hogy nagyon sok ingyenes vagy a várható haszonnál kisebb költséggel járó lehetôség áll a vállalatok elổtt környezetvédelmi tevékenységük javítására. Jól példázza az iménti állítást az alábbi három hazai vállalat:

- Ilyen változtatás volt például a Ganzair Kompreszszortechnika Kft-nél, amikor felismerték, hogy a sûrített levegốt használó gépeiket alacsonyabb nyomáson (a szokásos 8-10 helyett 6 baron) is ugyanolyan hatásfokkal lehet mũködtetni. Ez a külön beruházást nem igénylő fejlesztés egy gépen évente kétmillió forint megtakarítást eredményez. 
- A pécsi Biokom Kft egy beruházást nem igénylő módosítással évi hatmillió forintot takarít meg: a papírhulladékot a korábbi 250 kilós bálák helyett 400 kilós bálákba tömörítik, ezzel a megoldással a korábbi 15 tonna helyett 21 tonnányi papírt lehet egy teherautóval fuvarozni.

- Az adagolóiról ismert székesfehérvári Denso a fũtés és hûtés optimalizálásával évente 87 millió forintot takarít meg.

Egy környezetvédelemmel komolyan foglalkozó, ún. környezettudatos vállalat mindenképpen a szenynyezésprevencióra helyezi a hangsúlyt, és ezt az elvet kiterjeszti az általa elôállított termékek egész életciklusára, valamint folyamatosan új, tisztább technológiák kifejlesztésén munkálkodik (Hart, 1997).

\section{A szennyezésprevenció}

A környezetszennyezõ tevékenységet végzõ vállalatokat törvények kényszerítik egy bizonyos szintũ szennyezésmegelôzési, illetve -kezelési tevékenységre. Ezeket a törvényeket, szabályokat, kötelező standardokat a menedzserek sokáig költségnövelô, versenyképességet rontó, profitcsökkentô tényezôknek tartották. Ma már több szerzõ arra mutat rá, hogy a szigorú környezetvédelmi törvények és szabályok nem szükségszerũen járnak együtt a versenyképesség romlásával, éppen ellenkezôleg: az így kikényszerített folyamat-hatékonyságot növelỗ innovációk, a hatékonyabb nyersanyag- és energiafelhasználás költségcsökkenést, minôségjavulást, és végsô soron a versenyképesség javulását eredményezhetik (Funk, 2003; Kerekes - Szlávik, 2000; Porter - Linde 1995).

Porter és Linde (1995) szerint annak ellenére, hogy ezek a beruházások nyereségesek lehetnek, szükség van a szigorú szennyezésprevencióra koncentráló regulákra, mert a külsô nyomás serkenti az innovációkat eredményezõ kreatív gondolkodást, növeli annak az esélyét, hogy a termék- és folyamatinnovációk valóban környezetbarátok lesznek, és addig is védi az innovatív vállalatokat, amíg a beruházások eredményezte költségcsökkenés még nem jelenik meg.

Érdemes lehet a kötelezô szintnél tovább is elmenniük a vállalatoknak: Funk (2003) szerint a törvény által megkövetelt szinten túli környezetvédelmi beruházások versenyelônyt eredményezhetnek, amenynyiben újabb, a jövổben várható regulák elé mennek. Dowell, Hart és Yeung (2000) szignifikáns és pozitiv kapcsolatot találtak a vállalat piaci értéke és az alkalmazott környezeti standardok között, a kötelezônél szigorúbb környezeti standardok alkalmazása növeli a vállalat értékét. Az alacsony szintũ környezeti szabályo- zással rendelkezô fejlôdổ országokban mũködõ vállalatoknak is érdemes megvalósítaniuk a szigorúbb környezeti standardokat, mert ez később versenyelőnyt is eredményezhet számukra. Ugyanis nagy valószínũség szerint ezekben az országokban is - ahogy egyre nô a lakosság környezeti érzékenysége - szigorodni fog a törvényi szabályozás.

Walley és Whitehead (1994) nem osztják azt a nézetet, hogy a környezeti fejlesztések pénzügyi értéket termelnek egy vállalatnál. Szerintük a környezeti és üzleti megfontolások között trade-off-okat kell végrehajtaniuk a menedzsereknek, és a környezeti beruházások esetén is vizsgálni kell a hatékonyság és hatásosság (effectiveness és efficiency) kérdését.

Abban sok szerzõ egyetért, hogy minden szempontból hasznosabb a vállalati működés által okozott környezeti problémákat, baleseteket megelôzzni, mint utána a hibát helyrehozni (tetemes költség, imázsromlás) (Hunt -Auster, 1990; King-Lenox, 2002; Tahija, 1993).

De nemcsak azokat a károkat kell figyelembe venni, amelyek egy esetleges környezeti katasztrófa nyomán keletkeznek, hanem azokat a kevésbé nyilvánvaló károkat is, amelyek a folyamatos szennyezésből adódóan érik a vállalatot. A szennyezés ugyanis a gazdasági veszteség egyik speciális formája, az erôforrások nem hatékony kihasználásából ered (Lovins Lovins - Hawken, 1999; Porter - Linde, 1995), és a tökéletlen mũködés eredménye (Kleiner, 1991).

Kleiner (1991) rámutat, hogy - csakúgy, mint a sikeres minôségbiztosítás esetében, amikor a minôséget eleve beépítik a folyamatba, ahelyett hogy annak végén keresnék meg a hibákat - a környezetszennyezést is sokkal eredményesebben meg lehet akadályozni, ha a feldolgozási folyamatokból eleve kiiktatják a káros anyagokat, nem pedig a már kibocsátott szennyezōdéstôl próbál minél környezetkímélôbb módon megszabadulni a vállalat. Porter és Linde (1995) is párhuzamot vonnak a minôségmozgalom és a szenynyezésprevenció koncepciók között: a hatékonyabb input felhasználással, a veszélyes alapanyagok és a szükségtelen tevékenységek eliminálásával a folyamatminőség javítható. Ez költségcsökkenést és így versenyképesség javulást eredményezhet. Az inputok csökkentése, helyettesítése, újrafelhasználása, reciklálása, valamint a hulladékok mennyiségének csökkentésébôl adódó kisebb hulladéktárolási, -kezelési és szállítási költségek közvetlen megtakarításokat eredményeznek. Azzal Dowell, Hart és Yeung (2000) is egyetértenek abban, hogy sok esetben a termelési folyamat átalakításával csökkenteni, vagy akár eliminálni lehet a szennyezést. Nézzünk a fentebb leírtakra is három hazai vállalati példát! 
- A tisztító és kozmetikai szereket gyártó Egyesült Vegyimũvek Rt. korábban két termék elóállítása között vízzel mosta át gyártósorait, aminek következtében tetemes mennyiségũ szennyvízbírságot fizetett. 2001-ben átszervezték a termelést, azóta a hasonló alapanyagú és illatú termékeket gyártják egymás után, így a gépek nem kívánnak olyan alapos tisztítást. A vállalat így évi 900 köbméterrel kevesebb vizet fogyaszt, és 3,5 tonnával kevesebb terméket mos a csatornába.

- A Komárom-Esztergom Megyei Állami Közútkezelô Kht. az útkarbantartásnál lemaratott felsõ két aszfaltréteget korábban veszélyes hulladékként helyezte el, egy ideje viszont útépítéshez, javításhoz használja fel azt. 2001-2002-ben százezer tonna martaszfaltot dolgoztak így fel, és most már más közútfenntartóktól is átveszik ezt a hulladékot. (Magyarországon évi 140-180 ezer tonna martaszfalt-hulladék keletkezik.)

- Az összegyưjjtött hulladékot értékesíteni is lehet, és így kisebb-nagyobb bevételre tehet szert a vállalat. A Budapesti Erổmủ például a fémet hosszú ideje, az olajat és a tintapatronokat 2002 óta újrahasznosítja. Az elöbbi évi 100-120 tonna fémhulladék értékesítését jelenti, ez rendre 2,5 millió forintot hoz. Az olaj újrahasznosítása 1,5 millió forint bevételt hoz, és egyúttal 30 tonnával kevesebb veszélyes hulladékot eredményez, míg a körülbelül egy mázsa tintapatron értékesítése 80 ezer forintot hoz.

Senge és Carstedt (2001) szerint azonban attól, hogy egy környezetvédelmi beruházásnak köszönhetôen csökken a termelési folyamatban keletkezô hulladékok mennyisége, ám az előállított termékek száma és a kidobásukkal keletkezô hulladék mennyisége nem csökken, tehát a beruházás ténylegesen nem tekinthetô ökohatékonynak.

King és Lenox (2002) kutatásaikkal bizonyították, hogy a szennyezésmegelôzés - a szennyezés kezelésével szemben - pozitív hatással van a vállalat pénzügyi mutatóira (ROA) és nyereségességére.

Dowell, Hart és Yeung (2000) arra hívják fel a figyelmet, hogy a felelổs környezeti viselkedés okozta pozitív vállalati reputáció és imázsjavulás jótékonyan hat a vállalati értékre.

\section{Termékfelügyelet (Product stewardship)}

Kleiner (1991) szerint egy vállalat nem attól „zöld", hogy gyárt egy környezetbarát terméket, hanem attól, hogy hajlandó folyamatosan kísérletezni azzal, hogy az általa előállított termékek egész életciklusuk folyamán minél kevésbé terheljék a környezetet.
Ez a folyamat, illetve tevékenység a termékéletcikluselemzés, amely a „bölcsôtôl a sírig” vizsgálja a termékek környezetre gyakorolt hatását: magában foglalja az összes felhasznált anyag és energia vizsgálatát, valamint a gyártás, a használat és a hulladékká válás idején kibocsátott szennyezőanyag mértékének vizsgálatát (Rekettye, 1997). Egy vállalati példa:

- A Környezetbarát Termék Kht. által kidolgozott „Fekete-fehér irodai digitális másológépek” feltételrendszerének Magyarországon elôször a Ricoh Aficio 2035/2045 típusú berendezése felelt meg, elnyerve ezzel a védjegyhasználati jogot. A független Minổsítô Bizottság a multifunkciós berendezés értékelése során - a kiváló használhatósági tulajdonságokon túl - a gép teljes életciklusának környezeti hatását vizsgálta, a gyártástól a termék újra- hasznosításáig, mint pl. energiatakarékos üzemmód, alacsony zaj- és ózonkibocsátás, papír- és energiatakarékos funkciók, elektronikus dokumentumkezelés, környezetbarát csomagolás stb. A védjegyhasználati jog egyértelműen bizonyítja, hogy a Ricoh termékei nemcsak a magas szintũ technikai elvárásoknak felelnek meg, hanem - a környezettudatos vállalati filozófiának köszönhetôen több tulajdonságukban is jobbak a környezeti terhelésüket tekintve, mint a védjeggyel nem rendelkező, azonos funkciót betöltó termékek (www.ricoh.hu).

A környezettudatos vállalat törekszik a felhasznált energia- és alapanyag-mennyiség minimalizálására; a megújuló, újrahasznosított, környezetbarát alapanyagok, energiahordozók súlyának növelésére; a gyártás és szállítás során keletkezô bármilyen (talaj, levegõ, víz, zaj) szennyezés csökkentésére, az előállított termékek élettartamának és újrahasznosíthatóságának javítására stb.

Ahhoz, hogy a vállalatok az eddig használt alapanyagaikat újrahasznosított alapanyagokkal váltsák fel, nélkülözhetetlen, hogy a reciklált anyagok is jó minôségủek legyenek, versenyképes áron lehessen hozzájuk jutni, és elérhetôek legyenek akkor és olyan mennyiségben, ahogyan a vállalatnak szüksége van rájuk (Biddle, 1993).

Chen (2001) arra mutat rá, hogy komoly technikai kihívást jelent úgy környezetbarát termékeket gyártani, hogy közben ne kelljen feladni olyan fontos terméktulajdonságokat, mint például autók esetében a biztonság, a kényelem, a gyorsaság vagy éppen a vonzó külsô megjelenés. Egy környezetbarát terméktulajdonság beépítése gyakorta jár együtt egy vagy több másik termékjellemzô feladásával. Az autógyártás példájánál maradva az üzemanyag takarékosság a biz- 
tonság, a gyorsulás vagy éppen a luxus rovására mehet, az alacsony szennyezôanyag-kibocsátás korlátozhatja a maximálisan elérhetô sebességet, a reciklálhatóság pedig együtt járhat a minőségi konzisztencia romlásával (Chen, 2001). Azonban ezek a kompromiszszumok - mint azt a következő példa is mutatja - nem szükségszerũek:

- A Toyota a következôt nyilatkozza új hibridrendszerũ modelljérõl, a Priusról: „Ha a Priust vezeti, igazán nagy szolgálatot tesz a természetnek anélkül, hogy bármit is feláldozna a vezetés élményébõl." A rendszer alapja a teljesen egyedi, kombinált benzin és elektromos energia meghajtás, mely jelentősen csökkenti a jármũ fogyasztását, emellett minimalizálja a környezetre kifejtett káros hatást. Az eredmény közel fele akkora városi fogyasztás és CO2 kibocsátás, mint egy hasonló teljesítményũ benzinmotor által hajtott gépkocsi esetén. Ezen kívül a Priusnál akár $75 \%$-kal csökken a szmog kialakulását elōsegítõ nitrogén oxidok, szénmonoxidok és más káros szénvegyületek kibocsátása (www.toyota.hu).

A vállalatok kísérletet tehetnek termékeik életciklusának meghosszabbítására, így - egyéb elônyök mellett - a kidobással keletkezô hulladékmennyiség is csökkenne. Főként olyan iparágakban lehetne ennek jelentôsége (például számítástechnika), ahol a termékek rendkívül gyorsan elavulnak. Egy jobb stratégiával a vállalatok minimalizálni tudnák a termékavulás kockázatát, egy dizájnváltoztatás eredményeképp a fogyasztó az elavulttá váló terméket kidobás helyett fejleszthetné. Ez megnövekedett fogyasztói lojalitást, sőt - megfelelổ szolgáltatások hozzákapcsolásával hosszú távú kötôdést is eredményezhet (Funk, 2003).

Nagy kihívást jelent a vállalatok számára az elhasznált és kidobásra ítélt termékek visszavásárlása a fogyasztóktól. Ez egy visszairányuló logisztikai probléma (reverse logistics problem), amelyre vonatkozóan Toktay és társai (2000) kifejlesztettek egy modeltt, amely segítséget nyújt a vállalatoknak a rendszer mũködtetésében.

\section{Tisztább technológia}

Senge és Carstedt (2001) arra hívják fel a figyelmet, hogy az ipari termelésben is a természeti környezetre általánosan jellemzô ciklikus mũködést kellene megvalósítani, a jelenlegi lineáris gondolkodás helyett. A természet ugyanis hulladékok nélkül mũködik, ami egyik helyen szemét, az másutt táplálékká válik. A szerzôpáros javaslata szerint az iparban is ezt a „termel-reciklál-regenerál” körforgást kellene alkal- mazni, megváltoztatva a termelési folyamatokat úgy, hogy az egyik folyamat hulladéka egy másik folyamat alapanyagává tudjon válni.

Az ilyen radikális változásokat kiváltó, ún. fundamentális innovációkhoz a hagyományos gazdasági szempontokon túlmutató gondolkodásmódra van szükség. Figyelembe kell venni társadalmi és környezeti szempontokat is a döntés során. Ezek az innovációk sokkal komplexebbek (sokkal több érintettjük van), sokkal bizonytalanabbak (az érintettek eltérõ érdekei miatt) és sokkal kockázatosabbak, mint a hagyományos piacvezérelt innovációk. Hall és Vredenburg (2003) szerint csak az ilyen innovációk vezethetnek fenntartható fejlôdéshez (sustainable development innovation, SDI).

\section{Versenyelőny-e a vállalati környezettudatosság?}

Véleményem szerint erre a kérdésre nem létezik egyértelmũ igen-nem válasz, célszerũ a problémát úgy bevezetni, hogy „,attól függ”. De mitôl is függ?

Elôször is függ a megvalósítás módjától. Egy tudatos, jól koordinált, stratégiába integrált környezeti politika versenyelőnyt eredményezhet, amennyiben a versenytársak nem, vagy csak nehezen, lassan tudják lemásolni. Fontos, hogy a környezettudatosság alapvetổ érték legyen a vállalatnál, nemcsak vezetôi szinten, hanem az alkalmazottak körében is.

Másodszor, függ a megvalósítás idejétôl. Itt az elsôként lépõk, az innovátorok előnyeit hangsúlyoznám (Dowell - Hart - Yeung, 2000; Packard - Reinhardt, 2000; Porter - Linde, 1995). Erre az elônyre apellál például a GM és a Ford is a környezetbarát, üzemanyagcellás autók kifejlesztésével, amikor ugyanis az autózás költségei jelentôsen megnőnek, reményeik szerint ôk lesznek az elsők az új piacon (Packard - Reinhardt, 2000). Ugyan a Toyota már piacra lépett saját környezetbarát modelljével, a Toyota hibridrendszerü (THR) Priussal, de a még fejlesztés alatt lévô üzemanyagcellás megoldást a szakértôk jobb technikai megoldásnak tartják. Reinhardt (1999), valamint Dowell, Hart és Yeung (2000) a versenyelôny fontos forrásának tartják azt, ha a vállalat az éppen hatályos reguláknál szigorúbb környezetvédelmi fejlesztéseket hajt végre. Így amikor a törvények szigorodnak, ôk versenyelônybe kerülnek a fejlesztésekkel lemaradó konkurenciával szemben, sôt, lobbizhatnak is szigorúbb szabályokért, szándékosan hátrányba hozva riválisaikat. Az elsőként lépőknek van idejük arra, hogy olyan komplex, összefüggô rendszert (megkülönböztetô kompetenciát) hozzanak létre, megvalósítva a különbözõ funkciók stratégiai összhangját, amelyet az ún. útfüggôség érvényesülése miatt szinte lehetetlen utánozni. 
Harmadszor, függ a megvalósítás helyétôl. Itt elsôsorban az adott piac környezeti érzékenységére gondolok. Mint azt McGrath és társai (1996) hangsúlyozták, egy új kompetencia csak akkor válik versenyelổnnyé, ha azt - termékekbe, szolgáltatásokba ágyazva - sikerül eladni a fogyasztóknak. Von Hippel (1988) szerint ez pedig akkor lehetséges, ha a vállalat olyan terméket kínál a fogyasztóknak, amely számukra megkülönböztetô értéket nyújt, és ezáltal a költségeket jelentốsen meghaladó áron is hajlandóak azt megvenni. Chen (2001) állítása szerint a környezeti terméktulajdonságok jelentôsége a fogyasztók vásárlási döntéseiben egyre növekszik. Menon és Menon (1997) olyan fogyasztói felméréseket említenek, amelyek szerint az 1980-as évektổl kezdổoỏen folyamatosan nổ a vállalatok környezetvédelmi teljesítményét díjazó - illetve azokat környezetkárosító tevékenységeikért elítélỗ fogyasztói szegmens nagysága. A különbözõ piacok azonban különbözô mértékũ környezeti érzékenységet mutatnak. Ez függ a gazdaság fejlettségétől. Hansmeyer és Rürup vizsgálataikkal már 1973-ban igazolták, hogy a társadalmi fejlettség egy meghatározott szintjéhez meghatározott környezethasználat tartozik, és a környezeti célokért a magasabb jövedelmũek többet hajlandóak áldozni.

Véleményem szerint tehát abban az esetben tekinthetổ a vállalati környezeti orientáció versenyelônynek, ha az megkülönböztetổ kompetenciának számít a vállalat számára, egyedi és nehezen másolható piaci pozíciót eredményez, és van egy - a nyereséges mũködéshez elegendổ nagyságú - elérhetố fogyasztói szegmentum, amely értékeli a vállalat környezeti teljesítményét.

\section{Összefoglalás}

Az általam áttekintett nemzetközi (angol nyelvũ) szakirodalom alapján összefoglalásképpen a következô megállapításokat teszem:

- A növekvỗ mértékũ környezeti problémák miatt egyre szigorodó törvényi szabályozásnak és a fogyasztók fokozódó környezeti érzékenységének hála, mind több vállalat foglalkozik tevékenységének környezeti hatásaival, a természeti környezet védelmével.

- Növekvô azon vállalatok száma is, amelyek az elổbbi elvárásoknál szigorúbb belsô környezeti standardokat követnek, versenyelôny elérése céljából.

- Kutatások bizonyították, hogy a vállalati környezettudatosság - és az ebbôl következô pozitív reputáció - valóban jó hatással van a vállalat érté- kére (Dowell - Hart - Yeung, 2000) és pénzügyi mutatóira (King - Lenox 2002).

- Egy vállalat akkor érhet el ténylegesen versenyelổnyt, ha környezettudatos lépéseit megfelelổ módon teszi meg. A fenntartható fejlődés jegyében igyekszik kifejleszteni egyedi és másolhatatlan pozíciót létrehozó megkülönböztetố kompetenciát; ami áthatja a vállalat összes funkcióját, és kompatibilis a stratégiával. Ügyel az ehhez szükséges erôforrások, képességek és képzettségek meglétére mind vállalati, mind menedzseri, mind pedig alkalmazotti szinten; olyan értékekre helyezi a hangsúlyt, amelyeket egy megfelelỗ nagyságú, elérhetô fogyasztói szegmens ténylegesen értékel, és a költségeket meghaladó ár megfizetésével honorál.

- A vállalatnak ügyelnie kell a versenyelônny megtartására és megújítására is, hiszen semmilyen versenyelôny sem tart örökké.

- Egy környezettudatos vállalat a szennyezésmegelốzésre helyezi a hangsúlyt a szennyezéskezeléssel szemben; nemcsak a termelés környezeti hatásait vizsgálja, hanem termékei egész életciklusát figyelembe veszi; és törekszik új, tisztább technológiák kifejlesztésére (illetve átvételére), és eközben nem zárkózik el a radikálisan új megoldásoktól sem.

\section{Felhasznált irodalom}

Balachander, S. - K. Srinivasan (1994): Selection of Product Line Qualities and Prices to Signal Competitive Advantage; Management Science, július, 824-841 o.

Banerjee, S. B. - Iyer; E. S. - Kashyap, R. K. (2003): Corporate Environmentalism: Antecedents and Influence of Industry Type; Journal of Marketing, április, 106-122 o.

Biddle. D. (1993): Recycling for Profit: The New Green Business Frontier; Harvard Business Review, november-december, 1451560.

Chen, C. (2001): Design for the Environment: A Quality-Based Model for Green Product Development; Management Science, február, 250-263 0.

Collis, D. J. - Montgomery, C. A. (1995): Competing on Resources: Strategy in the 1990s; Harvard Business Review, július-augusztus, 118-128 o.

Dowell, G., - Hart, S. - Yeung, B. (2000): Do Corporate Global Environmental Standards Create or Destroy Market Value?; Management Science, augusztus 1059-1074 o.

Fisher; M. L. (1997): What Is the Right Supply Chain for Your Psoduct?; Harvard Business Review, március-április, 105-116 o.

Funk, K. (2003): Sustainability and Performance; Sloan Management Review, 2003 Winter, 65-70 o.

Glaskin, M. (1996): Catalist for Action; Unilever Magazine, 2/100 16-18 o. in: Mühlbacher, H. - Dahringer L. - Leihs. H. (1999): International Marketing 2nd Edition

Hall, J. - Vredenburg, H. (2003): The Challenges of Innovating for Sustainable Development; Sloan Management Review, 2003 Fall, 61-68 o.

Hansmeyer, K. H. - Rürup, B. (1973): Umweltgefährdung und Gesellschaftssysteme, Wirtschaftpolitische Chronik 22. Jg. 
1973. In: Kovács Anna: Környezeti marketing; Marketing \& Menedzsment, 1999/1. 47-51 o.

Hart, S. L. (1997): Beyond Greening: Strategies for a Sustainable World; Harvard Business Review, január-február, 6-76 o.

Hart, S. L. - Milstein. M. B. (1999): Global Sustainability and the Creative Destruction of Industries; Sloan Management Review, 1999 Fall, 23-33 o.

Hayes, R. H. - Pisano, G. B. (1994): Beyond World-Class: The New Manufacturing Strategy; Harvard Business Review, január-február, 77-86 0.

Holliday, C. (2001): Sustainable Growth, the DuPont Way: Harvard Business Review, szeptember, 129-134 o.

Hunt, C. B. - Auster, E. R. (1990): Proactive Environmental Management: Avoiding the Toxic Trap; Sloan Management Review, 1990 Winter, 7-18 o.

Kampas, P. J. (2003): Shifting Cultural Gears in TechnologyDriven Industries; Sloan Management Review, 2003 Winter, 41-48 o.

Kerekes S. - Szlávik .J. (2000): Zöld úton az EU felé? - Rómától Amszterdamig; Harvard Business Manager, 4/2000, 50-62 o.

King, A. - Lenox, M. (2002): Exploring the Locus of Profitable Pollution Reduction; Management Science, február, 289-299 o.

Kleiner, A. (1991): What Does it Mean to Be Green?; Harvard Business Review, július-augusztus, 38-47 o.

Lovins, A. B., - Lovins, L. H. - Hawken, P. (1999): A Road Map for Natural Capitalism; Harvard Business Review, május-június, 145-158 o.

McGrath, R. G., - Tsai, M. - Venkataraman, S. -MacMillan, I. C. (1996): Innovation, Competitive Advantage and Rent: A Model and Test; Management Science, március, 389-403 o.

Menon, A. - Menon, A. (1997): Enviropreneurial Marketing Strategy: The Emergence of Corporate Environmentalism as Marketing Strategy; Journal of Marketing, január 51-67 o.
Packurd, K. O. - Reinhardt, F. L. (2000): What Every Executive Needs to Know About Global Warming: Harvard Business Review, július-augusztus, 129-135 o.

Porter: M. E. (1996): What is Strategy?; Harvard Business Review, november-december, 61-78 o.

Porrer; M. E. - Linde, C. (1995): Green and Competitive; Harvard Business Review, szeptember-október, 120-134 o.

Reinhardt, F. L. (1999): Bringing the Environment Down to Earth; Harvard Business Review, jứlius-augusztus, 149-157 o.

Rekettye, G. (1997): Értékteremtés a marketingben; Közgazdasági és Jogi Könyvkiadó, Budapest

Senge, P. M. - Carstedt, G. (2001): Innovating Our Way to the Next Industrial Revolution: Sloan Management Review, 2001 Winter, 24-38 o.

Stalk, G. - Webher; A. M. (1993): Japan's Dark Side of Time; Harvard Business Review, július-augusztus, 93-102 o.

Tahija. J. (1993): Swapping Business Skills for Oil: Harvard Business Review, szeptember-október, 64-77 o.

Tokray, L. B., - Wein, L. M. - Zenios, S. A. (2000): Inventory Management of Remanufacturable Products: Management Science, november, 1412-1426 o.

Walley N. - Whirehead, B. (1994): It's not Easy Being Green; Harvard Business Review, május-június, 46-52 o.

von Hippel (1988): The Sources of Innovation; Oxford University Press, New York In: McGrath, R. G., M. Tsai, S. Venkataraman és 1. C. MacMillan (1996): Innovation, Competitive Advantage and Rent: A Model and Test; Management Science, március. 389-403 o.

Schumperer, J. A. (1950): Capitalism, Socialism and Democracy; 3rd edition, Harper \& Row, New York 